\title{
Effect of Azotobacter, Phosphate Solubilising Bacteria and Potash Mobilising Bacteria Inoculants on Productivity of Wheat (Triticum aestivum $\mathbf{L}$. )
}

\author{
B. C. Game*, B. M. Ilhe, V. S. Pawar and P. P. Khandagale \\ Agricultural Research Station, Niphad-422303, Dist. Nashik, Maharashtra, India \\ *Corresponding author
}

\section{A B S T R A C T}

\section{Keywords}

Wheat, biofertilizer, consortium, yield parameters, yield

Article Info

Accepted:

22 February 2020

Available Online:

10 March 2020
Experiment was carried out to study the effect of biofertilizers viz., Azotobacter, phosphate solubilizing bacteria and potash mobilizing bacteria, alone and in combinations along with different doses of inorganic fertilizers on yield of wheat. Highest number of tillers per hill (10.8), plant height $(98.71 \mathrm{~cm})$ and thousand grain weight $(43.09 \mathrm{~g})$ was recorded in seed treatment with MPKV Consortium $+100 \%$ RDF. Highest grain yield $(44.22 \mathrm{q} / \mathrm{ha})$ was also recorded in same treatment of MPKV Consortium $+100 \%$ RDF which was at par with treatment with $100 \%$ RDF (42.20 q/ha) while, the lowest wheat grain yield was recorded in absolute control treatment (28.16 q/ha). Seed treatment with MPKV consortium increased $2.64 \mathrm{q} /$ ha yield over control plot. Seed treatment with MPKV consortium along with recommended dose of fertilizer was found to be the best treatment in enhancing yield of wheat crop and increased $2.02 \mathrm{q} / \mathrm{ha}$ yield over the treatment in which only recommended dose of fertilizers was used. Soil nutrient status after crop harvest was found superior in the same treatment. Microbial activity in rhizosphere remained at elevated level in the treatment where biofertilizers inoculants were used but inorganic fertilizers were not added. The increment of yield and its components due to the biofertilizer inoculation may be attributed to the increase in nitrogen fixation, phosphate solubilization, potash mobilization and the production of plant growth promoting substances that enhance soil microbial activity that contributes towards the nutrient availability to plants. The application of biofertilizer increased the efficiency of both organic and inorganic fertilizers but alone was ineffective in increasing yield.

\section{Introduction}

Wheat (Triticum aestivum L.) is the second most important crop after rice in country, which contributes nearly one third of the total food grain production. Wheat is a staple food crop and is consumed by nearly 65 per cent of the population of India in the form of chapati and different bakery products. Wheat is grown all over India as a food security crop as it is having a great potential of producing good yield per unit area and grows well in almost all agro-climatic conditions. India is the largest wheat producing country in the world after China and accounts for more than 13 per cent of the world's wheat production. 
Nearly ninety per cent area under wheat cultivation is spread under irrigated conditions in the states of Punjab, Haryana, UP, MP, Rajasthan and Gujarat state. During 2018-19 Rabi season, India harvested record wheat production of 101.20 million tons from an area of 29.55 million hectare with the record average productivity of $34.24 \mathrm{q} / \mathrm{ha}$ (ICAR-IIWBR, 2019).

Fertilization plays important role in maximizing crop yield and hence farmers in general apply a high dose of chemical fertilizers during wheat production to harvest high grain yields. However, the heavy use of chemical fertilizers in agricultural farming has hazardous environmental impacts including degradation of soil fertility, organic matter absorption and decreased water holding capacity, nutrient mobilization and uptake by root zone (Xiao et al., 2019).

Due to harmful effects on the environment and human health, there is a new trend toward minimizing the use of chemical fertilizers and adoption of technology of bio-organic farming which is also known as sustainable agriculture. Bio-organic farming uses organic matter and beneficial microorganisms to provide healthy food associated with high quantity and quality while maintaining the environment (Mallik and Williams, 2008).

Organic manure and biofertilizers amendments are feasible ways to reduce chemical fertilizers application in wheat production without decreasing grain yields. Biofertilizers are the live formulation of microorganisms which have the ability to mobilize plant nutrients in the soil and offer a cheap, low capital intensive, non-bulk and eco-friendly source to boost productivity (Kloepper et. al., 1989). Among biofertilizers, Azotobacter play a key role in the nitrogen cycle in nature that binds atmospheric nitrogen inaccessible to plants and releasing it in the form of ammonium ions available to plants in the soil fixing an average $20 \mathrm{~kg} \mathrm{~N} / \mathrm{ha}$ per year. It is able to grow at a $\mathrm{pH}$ range of 4.8-8.5 and fixes $\mathrm{N}$ at optimum $\mathrm{pH}$ of 7.0-7.5 (Dilworth et al., 1988). Azotobacter increases about $10-12 \%$ yield of all the agriculture crop plants (Jaga and Singh, 2010). Azotobacter along with phosphate solubilizing bacteria and Potash mobilizing bacteria increases the grain yield of wheat as well as increases the availability of micronutrients like $\mathrm{Fe}, \mathrm{Mn}, \mathrm{Zn}$ etc in the soil and hence, the combined application of biofertilizers can considered as the beneficial for the growth and yield of wheat (Noreen and Noreen, 2014).

Biofertilizers are cost-effective relative to chemical fertilizers. They have lower manufacturing costs, especially regarding nitrogen and phosphorus use. In view of these facts, experiment was carried out to study the effect of biofertilizers viz., Azotobacter, Phosphate solubilizing bacteria, Potash mobilizing bacteria alone and in combinations alongwith different doses of inorganic fertilizers on growth and yield of wheat.

\section{Materials and Methods}

Field experiment was conducted during Rabi 2016-17, 2017-18 and 2018-19 at Agricultural Research Station, Niphad, Dist. Nashik, Maharashtra, the Wheat Research Centre under Mahatma Phule Krishi Vidyapeeth, Rahuri. The biofertilizers viz., Azotobacter, phosphate solubilising bacteria (PSB) and Potash mobilizing bacteria (KMB) and their combination (MPKV consortium) was produced and supplied for study by Biological Nitrogen Fixation Scheme, College of Agriculture, Pune. The experiment was laid out in randomized block design in three replications with different treatments of combinations of individual biofertilizers, consortium of biofertilizer and different levels of recommended dose of fertilizers (RDF). 
Seed of popular wheat variety NIAW 301(Trimbak) was treated with biofertilizers as per the following treatment details, dried in the shade and used for sowing.

1. Absolute control (without seed treatment)

2. $100 \%$ RDF

3. MPKV Azotobacter, PSB and KMB consortium (MPKV Consortium)

4. MPKV Consortium + 100\% RDF

5. $75 \% \mathrm{RDF}$

6. MPKV Consortium $+75 \%$ RDF

7. Azotobacter $+75 \% \mathrm{~N}+100 \% \mathrm{RD}$ of $\mathrm{P}$ and $\mathrm{K}$

8. $\mathrm{PSB}+75 \% \mathrm{P}+100 \% \mathrm{RD}$ of $\mathrm{N}$ and $\mathrm{K}$

9. $\mathrm{KMB}+75 \% \mathrm{~K}+100 \% \mathrm{RD}$ of $\mathrm{N}$ and $\mathrm{P}$

Sowing was done in $3.60 \mathrm{X} 3.00 \mathrm{~m}$ size plots with $22.5 \mathrm{~cm}$ row to row spacing in second week of November during all seasons. Graded level of the chemical fertilizers was applied as per treatment details. The trial was irrigated at an interval of 21 days. All the recommended cultivation practices were followed including plant protection measures. Observation on number of tillers and plant height was recorded at hard dough stage. Individual net plots were harvested at maturity. Observation on test weight and yield was recorded after cleaning the grains and drying them up to 13 to 14 per cent moisture content. Soil samples were collected from each treatment for microbial and soil nutrient status analysis. Initial and final cfu count of Azotobacter, PSB and $\mathrm{K}$ mobilizing bacteria was recorded on Jensen's media, Pikovskaya's agar media and modified Aleksandrov media, respectively. The experimental soil was analyzed for major nutrients as per standard protocols.

\section{Results and Discussion}

Overall the germination of wheat crop was satisfactory during all the crop seasons. On pooled analysis, the effect on number of tillers per hill due to different treatments was found statistically significant (Table 1).
Highest number of tillers per hill (10.8) was recorded in treatment 4 i.e. MPKV Consortium $+100 \%$ RDF which was at par with treatment 2 i.e. $100 \% \mathrm{RDF}$ (10.4) and treatment 7 i.e. Azotobacter $+75 \% \mathrm{~N}+100 \%$ $\mathrm{RD}$ of $\mathrm{P}$ and $\mathrm{K}$ (9.8), while significantly lowest number of tillers per hill were recorded in absolute control (6.2). Difference in plant height due to different treatments was also found statistically significant. Significantly lowest plant height $(83.53 \mathrm{~cm})$ was recorded in the control treatment. Highest plant height $(98.71 \mathrm{~cm})$ was recorded in treatment 4 i.e. MPKV Consortium + 100\% RDF followed by treatment 2 i.e. $100 \%$ RDF $(98.08 \mathrm{~cm})$. Seed treatment of MPKV consortium consisting Azotobacter, PSB and KMB alongwith recommended dose of fertilizer was found to be the best treatment in enhancing yield parameters of wheat crop and was superior to the treatment in which only recommended dose of fertilizers was given. Singh and Prasad (2011) reported that combined application of biofertilizers in wheat crop caused considerable increase in yield components over other treatments. Similar results have been reported by Singh et al., (2016) and Kushare et. al. (2009)

The difference in thousand grain weight was found statistically significant. Highest thousand grain weight (43.09 g) was recorded in treatment 4 i.e. MPKV Consortium $+100 \%$ RDF which was at par with treatment 2 i.e. $100 \%$ RDF (41.83 g). The lowest thousand grain weight was recorded in absolute control (37.66 g). Statistically significant difference was also recorded in grain yield due to different treatments. Highest grain yield (44.22 q/ha) was recorded in treatment 4 i.e. MPKV Consortium $+100 \%$ RDF which was at par with treatment 2 i.e. $100 \% \operatorname{RDF}(42.20$ $\mathrm{q} / \mathrm{ha})$. The lowest wheat grain yield was recorded in control treatment $(28.16 \mathrm{q} / \mathrm{ha})$. Seed treatment with MPKV consortium increased $2.64 \mathrm{q} / \mathrm{ha}$ yield over absolute control plot. It is revealed from the results 
that, seed treatment of MPKV consortium along with recommended dose of fertilizer was found to be the best treatment in enhancing yield of wheat crop and was superior to the treatment in which only recommended dose of fertilizers was used. There was 4.8 per cent increase in yield by addition of consortium of biofertilizers over the treatment in which only recommended dose of fertilizers was used. The increment of yield and its components due to the biofertilizer inoculation may be attributed to the increase in nitrogen fixation, phosphate solubilization, potash mobilization and the production of plant growth promoting substances that enhance soil microbial activity that contributes towards the nutrient availability to plants. The application of biofertilizer increased the efficiency of both organic and inorganic fertilizers but alone was ineffective in increasing yield. These results are in confirmity with the findings of Badr et al., (2009), Bahrani et al., (2010), Abbasi and Yousra (2012) and Mahato and Kafle (2013).

On analysis of soil samples for available N, P and $\mathrm{K}$ during all the three seasons (Table 2) it was found that maximum residual available nitrogen (198.2 $\mathrm{kg} \mathrm{ha}^{-1}$ ) and phosphorus (22.4 $\mathrm{kg} \mathrm{ha}{ }^{-1}$ ) was recorded in treatment 4 i.e. MPKV Consortium $+100 \%$ RDF, while maximum residual potash $\left(339.6 \mathrm{~kg} \mathrm{ha}^{-1}\right)$ was recorded in treatment 2 i.e. $100 \%$ RDF. Absolute control treatment recorded least available NPK kg ha ${ }^{-1}$ in soil after harvest.

There was increase in available nutrients in soil after harvest as compared to the initial count before sowing of crop. Increase in nutrients may be the result of microbial activity which attributed to the increase in nitrogen fixation, phosphate solubilization and potash mobilization. Present findings are in close conformity with the findings of ElHamid et al., (2013) who reported that, application of either organic amendments or bio fertilizer as individual or in combination improved microbial activity and fertility status of the soil.

Initial and final cfu count of Azotobacter, PSB and $\mathrm{K}$ mobilizing bacteria was recorded on Jensen's media, Pikovaskaya's agar media and modified Aleksandrov media, respectively (Table 2). Considerable increase in bacterial population during all the seasons was recorded in respective treatments in which microbial consortia was used. Maximum cfu count of Azotobacter (7.3 x $\left.10^{7}\right), \quad$ PSB $\left(6.0 \times 10^{7}\right)$ and $\mathrm{K}$ mobilizing bacteria $\left(4.8 \times 10^{7}\right)$ was recorded in the treatment T3 i.e. seed treatment with MPKV consortium.

The results denotes that the microbial activity remained at elevated level in the treatment where inoculation of Azotobacter, PSB and $\mathrm{KMB}$ was given without addition of chemical fertilizers. The findings are in conformity with the results of El-Sersawy et al., (1997) who reported improvements in microbial counts of Azotobacter, Azospirillum and phosphate dissolving bacteria. Narula et al., (2005) further reported that the root exudates play a significant role in the growth of microorganisms in the rhizosphere.

On comparative assessment of different treatments on monetary returns of wheat (table 3), it was found that seed treatment with MPKV Consortium $+100 \%$ RDF was the best treatment with highest benefit cost ratio (2.04) followed by treatment 2 i.e. $100 \%$ RDF (1.96). The least benefit cost ratio (1.53) was recorded in the control treatment. The higher economic returns in the best treatment was mainly due to higher yields with only Rs.225 additional cost of the treatment. Patra et al., (2019) reported that the biofertilizer inoculations gave higher net returns and B:C than uninoculated treatment. 
Table.1 Effect of different treatments on yield parameters and yield of wheat crop

\begin{tabular}{|c|c|c|c|c|c|}
\hline Treatment details & $\begin{array}{c}\text { Germination } \\
(\%)\end{array}$ & $\begin{array}{c}\text { No. of } \\
\text { tillers/ } \\
\text { hill }\end{array}$ & $\begin{array}{l}\text { Plant } \\
\text { height } \\
\text { (cm) }\end{array}$ & $\begin{array}{l}\text { TGW } \\
(\mathrm{g})\end{array}$ & $\begin{array}{l}\text { Yield } \\
\text { q/ha }\end{array}$ \\
\hline 1. Absolute control & 81.11 & 6.2 & 83.53 & 37.66 & 28.16 \\
\hline 2. $100 \%$ RDF & 89.67 & 10.4 & 98.08 & 41.83 & 42.20 \\
\hline 3. MPKV consortium & 86.67 & 7.6 & 86.04 & 38.33 & 30.80 \\
\hline 4. MPKV Consortium $+100 \%$ RDF & 91.89 & 10.8 & 98.71 & 43.09 & 44.22 \\
\hline $5.75 \%$ RDF & 84.44 & 8.5 & 95.82 & 39.40 & 38.11 \\
\hline 6. MPKV Consortium + 75\% RDF & 86.11 & 8.7 & 96.53 & 40.12 & 39.29 \\
\hline $\begin{array}{l}\text { 7. Azotobacter }+75 \% \mathrm{~N}+100 \% \mathrm{RD} \text { of } \mathrm{P} \\
\text { and K }\end{array}$ & 88.11 & 9.8 & 96.80 & 41.12 & 40.74 \\
\hline 8. PSB $+75 \% P+100 \%$ RD of $N$ and $K$ & 87.22 & 9.1 & 97.24 & 40.89 & 40.69 \\
\hline 9. $\mathrm{KMB}+75 \% \mathrm{~K}+100 \% \mathrm{RD}$ of $\mathrm{N}$ and $\mathrm{P}$ & 87.45 & 9.2 & 97.42 & 40.27 & 40.49 \\
\hline S.E. \pm & & 0.37 & 0.99 & 0.56 & 1.15 \\
\hline C.D. at $5 \%$ & & 1.05 & 2.80 & 1.58 & 3.26 \\
\hline
\end{tabular}

$\mathrm{PSB}=$ Phosphate solubilising bacteria

$\mathrm{KMB}=$ Potash mobilizing bacteria

MPKV consortium = Consortium of MPKV's Azotobacter strain, PSB and KMB

Table.2 Effect of different treatments on chemical and biological properties of soil (Average of 3 years data)

\begin{tabular}{|c|c|c|c|c|c|c|}
\hline \multirow[t]{2}{*}{ Treatment details } & \multicolumn{3}{|c|}{$\begin{array}{l}\text { Available } \\
\left(\mathrm{Kg} \mathrm{ha}^{-1}\right)\end{array}$} & \multicolumn{3}{|c|}{ Microbial count X $10^{7}$} \\
\hline & $\mathbf{N}$ & $\mathbf{P}$ & $\mathbf{K}$ & Azotobacter & PSB & KMB \\
\hline 1. Absolute control & 122.7 & 14.3 & 295.4 & 2.8 & 3.7 & 2.3 \\
\hline 2. $100 \%$ RDF & 173.6 & 20.0 & 339.6 & 2.2 & 3.0 & 2.2 \\
\hline 3. MPKV consortium & 150.8 & 18.0 & 329.8 & 7.3 & 6.0 & 4.8 \\
\hline 4. MPKV Consortium + $100 \%$ RDF & 198.2 & 22.4 & 337.6 & 5.0 & 5.3 & 4.1 \\
\hline 5. $75 \%$ RDF & 156.1 & 19.0 & 328.7 & 2.2 & 3.5 & 2.1 \\
\hline 6. MPKV Consortium + 75\% RDF & 185.4 & 20.9 & 334.3 & 5.8 & 5.2 & 4.3 \\
\hline $\begin{array}{l}\text { 7. Azotobacter }+75 \% \mathrm{~N}+100 \% \text { RD of P } \\
\text { and K }\end{array}$ & 191.5 & 20.9 & 338.8 & 6.6 & 3.8 & 2.3 \\
\hline 8. PSB $+75 \% P+100 \%$ RD of $N$ and $K$ & 182.3 & 22.2 & 334.6 & 3.4 & 5.9 & 2.4 \\
\hline 9. $K M B+75 \% \mathrm{~K}+100 \% \mathrm{RD}$ of $\mathrm{N}$ and $\mathrm{P}$ & 168.4 & 19.6 & 327.3 & 3.2 & 3.0 & 4.6 \\
\hline
\end{tabular}


Table.3 Comparative assessment of different treatments on monetary returns of wheat

\begin{tabular}{|l|c|c|c|c|c|}
\hline Treatment details & $\begin{array}{c}\text { Yield } \\
\text { q/ha }\end{array}$ & $\begin{array}{c}\text { Gross } \\
\text { returns } \\
\text { (Rs/ha) }\end{array}$ & $\begin{array}{c}\text { Cost of } \\
\text { cultivation } \\
\text { (Rs/ha) }\end{array}$ & $\begin{array}{c}\text { Net } \\
\text { returns } \\
\text { (Rs/ha) }\end{array}$ & $\begin{array}{c}\text { B:C } \\
\text { ratio }\end{array}$ \\
\hline 1. Absolute control & 28.16 & 59136 & 38750 & 20386 & $\mathbf{1 . 5 3}$ \\
\hline $\mathbf{2 . 1 0 0 \% ~ R D F ~}$ & 42.20 & 88620 & 45270 & 43350 & $\mathbf{1 . 9 6}$ \\
\hline 3. MPKV consortium & 30.80 & 64680 & 38975 & 25705 & $\mathbf{1 . 6 6}$ \\
\hline 4. MPKV Consortium + 100\% RDF & 44.22 & 92862 & 45495 & 47367 & $\mathbf{2 . 0 4}$ \\
\hline $\mathbf{5 . 7 5 \%}$ RDF & 38.11 & 80031 & 43640 & 36391 & $\mathbf{1 . 8 3}$ \\
\hline 6. MPKV Consortium + 75\% RDF & 39.29 & 82509 & 43865 & 38644 & $\mathbf{1 . 8 8}$ \\
\hline $\mathbf{7 . ~ A z o t o b a c t e r ~ + ~ 7 5 \% ~ N ~ + ~ 1 0 0 \% ~ R D ~ o f ~ P ~}$ & 40.74 & 85554 & 45045 & 40509 & $\mathbf{1 . 9 0}$ \\
\hline and K & & & & & \\
\hline 8. PSB + 75\% P + 100\% RD of N and K & 40.69 & 85449 & 44715 & 40734 & $\mathbf{1 . 9 1}$ \\
\hline 9. KMB + 75\% K + 100\% RD of N and & $\mathbf{4 0 . 4 9}$ & $\mathbf{8 5 0 2 9}$ & $\mathbf{4 5 0 9 5}$ & $\mathbf{3 9 9 3 4}$ & $\mathbf{1 . 8 9}$ \\
\hline P & & & & & \\
\hline
\end{tabular}

Total cost of cultivation excluding inorganic fertilizers and biofertilizers: Rs.38750/-

Average selling rate of wheat: Rs.2100/q

All the biofertilizer inoculations were statistically at par with each other in all the economic parameters. The above findings are also in conformity with those reported by Gupta (2002). There is a scope of increasing wheat crop yields through the use of biofertilizers with different inorganic fertilizer levels. The biofertilizers increased yield components and yield of wheat, improve soil nutrients balance, increase microbial activity in the rhizosphere and minimize environmental pollution.

Biofertilizer inoculants like Azotobacter, phosphate solubilising bacteria and Potash mobilizing bacteria alone and in combinations with inorganic fertilizers can be used as a supplement to inorganic fertilizer and farmyard manure to increase the yield to the maximum. The dependency on the increased dose of inorganic fertilizer for higher productivity can be reduced. Among the benefits of using bioferilizers is the reduction in cost of cultivation as compared with the use of full dose of inorganic fertilizers. It is extremely important for sustaining production and improving the fertility of soils. But, biofertilizer alone is ineffective in increasing productivity of wheat crop.

\section{Acknowledgements}

Authors are thankful to the Wheat Specialist, Agricultural Research Station, Niphad, Dist. Nashik, Maharashtra for providing necessary facilities during the investigations and the Microbiologist, Biological Nitrogen Fixation Scheme, College of Agriculture, Pune, Maharashtra for supplying biofertilizers and its consortium.

\section{References}

Abbasi, M.K. and Yousra, M. 2012. Synergistic effects of biofertilizer with organic and chemical $\mathrm{N}$ sources in improving soil nutrient status and increasing growth and yield of wheat grown under greenhouse conditions. Plant Biosystems. 146(Sup 1):181-189.

El-Hamid, A., Azza, R., AL-Kamar, F.A. and Husein, M.E. 2013. Impact of some 
organic and biofertilizers soil amendments on the fertility status, some soil properties, and productivity of sandy soils. Journal of Soil Sciences and Agricultural Engineering. 4(10):989-1007.

Badr, E.A., Ibrahim, O.M. and El-Kramany, M.F. 2009. Interaction effect of biological and organic fertilizers on yield and yield components of two wheat cultivars. Egypt. J. Agron. 31(1):17-27.

Bahrani, A., Pourreza, J. and Joo, M.H. 2010. Response of winter wheat to coinoculation with Azotobacter and Arbescular Mycorrhizal Fungi (AMF) under different sources of nitrogen fertilizer. American-Eurasian J. Agric. \& Environ. Sci. 8(1):95-103.

Dilworth, M.J., Eady, R.R. and Eldridge, M.E. 1988. The vanadium nitrogenase of Azotobacter chroococcum. Reduction of acetylene and ethylene to ethane. Biochem. J. 249(3):745-751.

El-Sersawy, M.M., Abd-El-Ghany, B.F., Khalil, K.W. and Awadalla, S.Y. 1997. Interaction between organic manure mixtures, applied N-level and biofertilization on calcareous soil properties and wheat production in Wadi Sudr, South Sinai [Egypt]. Egyptian J. Soil Sci. 37:367-397.

Gupta, Trilok Chand. 2002. Integrated nutrient management in wheat (Triticum aestivum L.). Ph.D. Thesis submitted to CCS HAU, Hisar.

ICAR-IIWBR. 2019. Director's Report of AICRP on Wheat and Barley 2018-19, Ed: G.P. Singh. ICAR- Indian Institute of Wheat and Barley Research, Karnal, Haryana, India. P72.

Jaga, P.K. and Singh, V. 2010. Effect of biofertilizer, nitrogen and sulphur on sorghum-mustard cropping system. In: Proceedings of National Seminar on Soil Security for Sustainable
Agriculture held at College of Agriculture, Nagpur.

Kloepper, J.W., Lifshitz, R. and Zablotowicz, R.M. 1989. Free-living bacterial inocula for enhancing crop productivity. Trends in Biotechnology. 7(2):39-44.

Kushare, B.M., Kushare, Y.M. and Sandhan, V.S. 2009. Effect of $\mathrm{N}$ and $\mathrm{P}$ levels and biofertilizers on the growth and yield of wheat under late sown irrigated conditions. International Journal of Agricultural Sciences. 5(2):424-427.

Mahato, S. and Kafle, A. 2013. Comparative study of Azotobacter with or without other fertilizers on growth and yield of wheat inWestern hills of Nepal. Annals of Agrarian Science. 16: 250-256.

Mallik, M.A., Williams, R.D. 2008. Plant growth promoting rhizobacteria and mycorrhizal fungi in sustainable agriculture and forestry. In: Zeng, R.S., Mallik, A.U., Luo S.M., eds. Allelopathy in sustainable agriculture and forestry. New York: Springer. 321345.

Narula, N., Kumar, V., Singh, B., Bhatia, R. and Lakshminarayana, K. 2005. Impact of Biofertilizers on grain yield in spring wheat under varying fertility conditions and wheat-cotton rotation. Archives of Agronomy and Soil Science. 51(1):7989.

Noreen, F. and Noreen, S. 2014. Effect of different fertilizers on yield of wheat. International Journal of Science and Research. 3 (11):1596-1599.

Patra, B., Singh, J., Hooda V.S. and Kapoor, A. 2019. Effect of seed priming, bio fertilizer inoculations and nitrogen levels on yield attributes, yield and economic returns of late sown wheat. International Journal of Chemical Studies. 7(3): 95-99.

Singh, M.P., Kumar, P., Kumar, A., Kumar, R., Diwedi, A., Gangwar, S., Kumar, V. and Naval Kumar. 2016. Effect of NPK 
with biofertilizers on growth, yield and nutrient uptake of wheat (Triticum aestivum L.) in Western Uttar Pradesh condition. Prog. Agric. 16(1):83-87

Singh, R.R. and Prasad, K. 2011. Effect of bio-fertilizers on growth and productivity of wheat (Triticum aestivum). Journal of Farm Sciences.
1(1): $1-8$.

Xiao, G., Zhao, Z., Liang, L., Meng, F., Wu, W. and Guo, Y. 2019. Improving nitrogen and water use efficiency in a wheat-maize rotation system in the North China Plain using optimized farming practices. Agric. Water Manag. 212:172-180.

\section{How to cite this article:}

Game. B. C., B. M. Ilhe, V. S. Pawar and Khandagale. P. P. 2020. Effect of Azotobacter, Phosphate Solubilising Bacteria and Potash Mobilising Bacteria Inoculants on Productivity of Wheat (Triticum aestivum L.). Int.J.Curr.Microbiol.App.Sci. 9(03): 2800-2807. doi: https://doi.org/10.20546/ijcmas.2020.903.322 